\title{
National equipment of intraoperatory gamma detection in the identification of sentinel lymph node in animal model ${ }^{1}$
}

\author{
Equipamento nacional de detecção gama intra-operatória na identificação de linfonodo \\ sentinela
}

\author{
Paula Cristina Fada dos Santos ${ }^{\mathrm{I}}$, Ivan Dunshee de Abranches Oliveira Santos ${ }^{\mathrm{II}}$, Fábio Xerfan Nahas ${ }^{\mathrm{III}}$, Renato Santos de Oliveira \\ Filho $^{\text {IV }}$, Lydia Masako Ferreirav \\ ${ }^{\text {I }}$ Fellow Master degree, Post-graduate Program on Plastic Surgery, UNIFESP, Sao Paulo, Brazil. \\ ${ }^{\text {II }} \mathrm{PhD}$, Head, Division of Plastic Surgery, Department of Surgery, UNIFESP, Sao Paulo, Brazil. \\ III PhD, Affiliate Professor, Division of Plastic Surgery, Department of Surgery, UNIFESP, Sao Paulo, Brazil. \\ ${ }^{\text {IV }} \mathrm{PhD}$, Faculty of Medicine, University of Sao Paulo, Brazil. \\ v PhD, Full Professor, Head, Division of Plastic Surgery, Department of Surgery, Coordinator of the Post-graduate Program on Plastic Surgery, UNIFESP, \\ Sao Paulo, Brazil.
}

\begin{abstract}
Purpose: To investigate a national equipment of intraoperatory gamma detection in the identification of sentinel lymph node. Methods: Thirty young adult male rats were used. After anesthetized, animals were divided into two groups of 15 animals each. Animals from group A received dextram $500-\mathrm{Tc}^{99}$ radiopharmaceutical and patent blue $\mathrm{V}$ and those from group $\mathrm{B}$ received only patent blue $\mathrm{V}$ to map the lymphatic drainage. The presence of radiation in the background area, in the area of injection and of the ex vivo sentinel lymph node of group A were measured. After the exeresis, each lymph node in group A and in group B was mixed forming a new random sequence and the radioactive reading of each lymph node was carried out, using both pieces of equipment. Results: The hottest sentinel lymph node was identified by the national equipment when radiation was measured in the area of limphatic drainage after the Dextran 500 was injected. Also, the ex vivo sentinel lymph node. The national equipment has also detected radiation in the lymph nodes that had not received radiopharmaceutical, leading to false positive, checked by the application of Mann-Whitney tests and Student's paired t-tests. The Cronbach alpha has shown high internal consistency of data 0,9416. Conclusions: The national equipment of intraoperatory gamma detection identifies the LS and showed false positives LS and needs improvement.
\end{abstract}

Key words: Sentinel Lymph Node Biopsy. Equipment. Research Design. Rats.

\section{RESUMO}

Objetivo: Investigar o equipamento nacional de detecção gama intra-operatória na identificação de linfonodo sentinela. Métodos: Foram utilizados 30 ratos machos, adultos jovens. Depois de anestesiados, os animais foram distribuidos em dois grupos de 15 animais cada. O grupo A recebeu radiofármaco dextran 500 - $\mathrm{Tc}^{99}$ e azul patente $\mathrm{V}$ e o grupo B, somente azul patente V para realização do mapeamento linfático. Foi realizada a medição da captação radioativa da região de fundo, do sítio de injeção e do linfonodo sentinela ex vivo do grupo A. Após a exérese, cada linfonodo do grupo A e do grupo B foram misturados formando uma nova seqüência aleatória e procedeu a leitura da radioatividade de cada linfonodo com os dois equipamentos. Resultados: O linfonodo sentinela hipercaptante foi identificado pelo equipamento nacional durante as medições da captação radioativa na região do sítio de injeção e linfonodo sentinela ex vivo. O equipamento nacional detectou radiação mesmo nos linfonodos que não receberam o radiofármaco, causando falso positivo, verificado na aplicação dos testes de Mann-Whitney e t pareado de Student. O alfa de Cronbach mostrou alta consistência interna dos dados (0,9416). Conclusões: O equipamento nacional de detecção gama intra-operatória identifica o linfonodo sentinela e mostra falsos positivos e necessita de aprimoramento.

Descritores: Biópsia de Linfonodo Sentinela. Equipamento. Projetos de Pesquisa. Ratos.

${ }^{1}$ Research performed at Plastic Surgery Experimental Laboratory, Post-graduate Program in Plastic Surgery, Division of Plastic Surgery, Department of Surgery, Federal University of Sao Paulo (UNIFESP), Brazil. 


\section{Introduction}

The use of intraoperatory gamma detection has already been established in oncology to identify sentinel lymph nodes in melanoma ${ }^{1-4}$, in breast cancer ${ }^{5-10}$ and its application for other tumors such as vulva ${ }^{8-10}$. Also, its use in head and neck ${ }^{11}$ cancer is being studied. Today the sentinel lymph node biopsy procedure is considered to be essential and indispensable. Besides its high sensitivity to detect lymph nodes, the IGD allows for lower dissection, making the procedure less invasive. The SLB has reduced the number of unnecessary radical lymphadenectomies, thus reducing the surgical morbidity,7,4,12-16.

The sentinel lymph node (SL) is defined as the first lymph node of the lymph nodal basis to which the drainage of the primary tumor occurs ${ }^{17,18}$. The SLB in melanoma was established by Morton et $a l .{ }^{19}$, at first only using the vital blue dye that allows for the microstaging of solid tumors. These tumors, in the beginning, spread preferably through the lymphatic system. The IGD has already been included in the official staging of melanoma and of breast cancer in accordance with the AJCC/UICC (American Joint Committee on Cancer Staging System) $)^{20}$.

The combination of the lymphatic mapping with the vital blue dye and the intraoperatory gamma detection in the SBL has been shown as a more sensitive combination of methods to detect $\mathrm{SL}^{4,7,8,10,21-23}$. The accuracy to find the SL with this association is high, ranging between $98-100 \%{ }^{24-30}$.

Today, there are several pieces of equipment commercially available to carry out the intraoperatory gamma detection such as Neoprobe $^{\circledR}$, Europrobe ${ }^{\circledR}$, Navigator ${ }^{\circledR}$. However, most pieces of equipment are imported and expensive, which a lot of times limits their use to large centers ${ }^{31,32}$. They basically have a probe with a crystal or small gamma camera in one end, which is connected to a portable counter. In our country, Oliveira Filho et al. ${ }^{14}$ carried out a clinical investigation of the selective lymphadenectomy with the SLB, using vital blue dye (patent blue V) and IGD, confirming the data in the literature and its technical reproductibility.

Costa et $a l .{ }^{31}$ have developed a piece of national intraoperatory gamma detection equipment, which has a radioguided surgical probe. They carried out tests with doctors that found the device friendly to use and aimed to get the product to the market at a lower cost. Most importantly is the acess to maintenance, as imported equipment has to be sent abroad for maintenance.

Consequently, it is imperative that experiments are made to demonstrate feasibility of this new equipment.

\section{Methods}

This study was approved by the Ethics Committee on Animal Experimentation of the Federal University of Sao PauloUNIFESP, and was conducted under the guidance and supervision of the Center for Radiation of the Federal University of Sao Paulo (UNIIFESP). For the continuation of the study, it was used equipment imported from Europrobe ${ }^{\circledR}$ brand, serial number: 00,139, model: $506,160,014$. The equipment was made available by the Office of Diagnostic Imaging of the Samaritan Hospital. The equipment's national IPEN (patent MU8602566-0) model III, was handled in accordance with the instructions of the unit.

Thirty young adult 250 to $300 \mathrm{~g}$ male Wistar EPM-1 rats (Rattus novergicus: var. albinus, Rodentia, Mammalia) from the
Animal Colony of the Federal University of Sao Paulo were studied. All procedures were performed in accordance with the ethical principles defined by the Brazilian College of Animal Experiments (COBEA).

The animals, under the same environmental conditions, were submitted to lymphatic mapping with vital blue dye, intraoperatory gamma detection and sentinel lymph node exeresis.

Each animal was anesthetized with $25 \mathrm{mg} / \mathrm{kg}$ of tiletamine chloridrate and $25 \mathrm{mg} / \mathrm{kg}$ of zolazepam chloridrate with syringe and insulin needle, injected in the peritoneal cavity, in the lower left quadrant of the abdomen. In this dosage, the anesthesia lasts around 120 to 180 minutes.

The animals were dstributed into two groups of fifteen animals each. The animals of the first group (group A) were submitted to the injection of $0.1 \mathrm{ml}(10 \mathrm{uCi})$ of dextran $500-\mathrm{Tc}^{99}(\mathrm{IPEN})$ radiopharmaceutical in the plantar cushion of the right posterior limb. After that, $0.1 \mathrm{ml}$ of patent blue V (Guerbet) was injected in the same place to carry out the lymphatic mapping.

First, the radiation in the left axillary region was measured (background reading) and then the one in the place of the injection. These measurements were always made both with the imported and the national devices.

Five minutes after the patent blue injection, a single incision was made from the skin in the popliteal region to the inguinal area to carry out the biopsy of the sentinel lymph node, checking if the lymph note was blue dyed by the patent blue or not. Then, the popliteal lymph node (sentinel) in the popliteal cavity was identified and removed.

During surgery, the two gamma radiation detectors were alternately used in sequence, one after the other. Individual cards were used for each of the animals to take notes of the data with reference to each piece of equipment and the radiation reading values in both. Use of the equipment under study was according to its instruction's manual.

After the exeresis, the dyed hottest sentinel lymph node of each animal from group A was identified with numbers (from 1 to 15$)$ by the researcher and placed in separate recipients.

The other group of 15 animals (group B) underwent only the lymphatic mapping with vital blue dye and sentinel lymph node exeresis, following all the procedures used in group A, except for the injection of the radiopharmaceutical. After the exeresis of the sentinel lymph node of each animal in group B, they were identified with numbers (from 16 to 30 ) by the researcher and placed in separate recipients.

The 30 lymph nodes numbered from 1 to 30, were randomly distributed forming a new sequence. Another observer, who didn't know the random sequence of the lymph nodes, measured the radiation in each lymph node with both pieces of equipment.

After the exeresis of the SL, the animals were subjected to euthanasia with a hyper dose of anesthetic. The animals were disposed according to the protocol of the Radiological Protect Unit.

\section{Statistical analysis}

To check discrepancies between the results reached with the conventional equipment and the IPEN equipment, Mann Whitney tests were used. The discrepancies between the pairs of results measured with the conventional piece of equipment were compared to the IPEN piece of equipment were evaluate using the 
Student's paired t-test. The Cronbach Alpha was applied to check the internal consistency of the data. Five percent was used as the level of significance.

\section{Results}

The IPEN equipment detected radiation even in lymph nodes which had not received the radiopharmaceutical, leading to a false-positive, as verified by the Mann-Whitney's test and Student's paired-t testes). This was found when the values of gamma radiation measured with the pieces of intraoperatory gamma detection equipment of each ex vivo sentinel lymph node were analyzed (Table 1) - Cronbach Alpha showed a high internal consistency of the data (0.9188). In background area (Table 2), the Cronbach Alpha showed a low internal consistency of data (0.4690).

In the area of the injection, a discrepancy between the pairs of results of both pieces of equipment $(p=0.0013)$ was observed, but MannWhitney's test could not detect differences between the two groups of results (Table 3). The Cronbach Alpha showed high internal consistency of data (0.9416).

Although both devices determined which was the SL, no statistical significant differences were found between the gamma radiation values of the ex vivo sentinel lymph node by the two pieces of intraoperatory equipment (Table 4). The Cronbach Alpha showed high internal consistency of data (0.9251).

\section{Discussion}

The use of radioguided surgery in the intraoperatory location of the sentinel lymph nodes has brought new possibilities in the treatment of tumor metastases. There are criteria that guide the evaluation of radioguided probes in this type of application and define the minimum necessary requirements. The Nema Standarts Publication Nu 3-2004 Performance Measurements and Quality Control Guidelines for Non-Imaging Intraoperative Gamma Probes published by the National Electrical Manufactures Association aims at standardizing performance measurements of radioguided probes for intraoperatory use ${ }^{31}$.

The intraoperatory gamma detection probe developed by Costa et al. ${ }^{31}$ has shown that the physical characteristics have met the suggested proposals in international publications to be used as radioguided probes in the location of sentinel lymph nodes, marked with ${ }^{99 \mathrm{~m}} \mathrm{Tc}$.

Oliveira-Filho et al. ${ }^{14}$ described that the sentinel lymph node is found in around $83 \%$ to $100 \%$ of the cases, varying according to the location of the region of the sentinel lymph node. In the inguinal cases, $100 \%$ of success was reached only
TABLE 1 - Comparison between the values of gamma radiation reading using the international and the IPEN intraoperatory gamma detection equipments of each extirpated sentinel lymph node

\begin{tabular}{lccc}
\hline & International & IPEN & Paired-t test \\
\hline $\mathrm{n}$ & 30 & 30 & \\
Average & 29,6 & 40,2 & \\
Standard Deviation & 38,9 & 26,5 & $\mathrm{t}=3,18$ \\
Median & 8,5 & 26,0 & $\mathrm{p}=0,0034^{*}$ \\
Minimum & 0 & 13 & \\
Maximum & 116 & 93 & \\
\hline Mann-Whitney Test & $\mathrm{U}=293,0$ & $\mathrm{p}=0,020$ & \\
Cronbach's Alpha $=0,9188$ & & & \\
$*$ Statistically significant difference & &
\end{tabular}

TABLE 2 - Comparison between the values of radiation reading in the background of injection by using the International and the IPEN

\begin{tabular}{lccc}
\hline & International & IPEN & Paired-T test \\
\hline $\mathrm{n}$ & 15 & 15 & \\
Average & 3,7 & 23,5 & \\
Standard Deviation & 1,4 & 8,2 & $\mathrm{t}=11,03$ \\
Median & 4,0 & 27,0 & $\mathrm{p}<0,00001^{*}$ \\
Minimum & 2 & 11 & \\
Maximum & 6 & 33 & \\
\hline Mann-Whitney Test & $\mathrm{U}=0,0$ & $\mathrm{p}<0,00001$ & \\
Cronbach's Alpha $=0,469$ & & & \\
* Statistically significant difference & &
\end{tabular}

TABLE 3 - Comparison between the values of radiation reading in the injection area using the International and the IPEN intraoperatory gamma detection equipment

\begin{tabular}{lccc}
\hline & International & IPEN & Paired-t test \\
\hline $\mathrm{n}$ & 15 & 15 & \\
Average & 2824,7 & 3901,5 & \\
Standard Deviation & 1799,8 & 2583,9 & $\mathrm{t}=3,99$ \\
Median & 3639,0 & 4688,0 & $\mathrm{p}=0,0013^{*}$ \\
Minimum & 557 & 729 & \\
Maximum & 5176 & 7142 & \\
\hline Mann-Whitney Test & $\mathrm{U}=68,0$ & $\mathrm{p}=0,067-\mathrm{ns}$ & \\
\hline Cronbach's Alpha = $=0,9416$ & & & \\
$*$ Statistically significant difference & &
\end{tabular}

TABLE 4 - Comparison between the values of radiation reading of the ex vivo SLN using the International and the IPEN intraoperatory gamma detection equipament

\begin{tabular}{lccc}
\hline & International & IPEN & Paired-T Test \\
\hline $\mathrm{n}$ & 15 & 15 & \\
Average & 78 & 80 & \\
Standard Deviation & 45,9 & 30,4 & $\mathrm{t}=0,36$ \\
Median & 76 & 76,5 & $\mathrm{p}=0,7218-\mathrm{ns}$ \\
Minimum & 31 & 10 & \\
Maximum & 129 & 161 & \\
\hline Mann-Whitney Test & $\mathrm{U}=112,0$ & $\mathrm{p}=1,00-\mathrm{ns}$ & \\
\hline Cronbach's Alpha $=0,9251$ & & &
\end{tabular}


with the vital blue dye, but in other locations the lymph cintilography and the intraoperatory gamma radiation detector are important.

The internal consistency of each piece of equipment was studied by means of the Cronbach Alpha analysis. The high internal consistency of data of each extirpated sentinel lymph node was 0.9188 and the low internal consistency of data in the area of the background area was 0.4690 (Table 2).

The IPEN equipment detected radiation even in lymph nodes that had not received the radiopharmaceutical, leading to a false positive, as verified by the application of Mann-Whitney's test and Student's paired-t test. On the other hand, The IPEN equipment found radiation and the hottest sentinel lymph node by means of sound guidance and also the number scale showed a level above the background values.

Costa et al. ${ }^{31}$ reported that because of the high penetrability of gamma rays,radiation can be detected in any part of the patient and not only at the desired area. This situation implies that the detection should not only present high energy resolution, but also the capability to spatially reject undesirable gamma rays which might be reflected over the detector. Therefore false positive readings can be found in normal areas with radioactivity, leading to a diagnostic error.

These results give basis to the possibility to use the national intraoperatory gamma detection equipment in human beings.

\section{Conclusions}

1. The national equipment of intraoperatory gamma detection identifies the LS;

2. The national equipment of intraoperatory gamma detection showed false positives LS and needs improvement.

Certainly, this study will serve as the basis to use the national equipment to identify the sentinel lymph node in human beings so that the procedure can become more accessible and less expensive.

\section{References}

1. Alex JC, Krag DN. Gamma-probe guided localization of lymph nodes. Surg Oncol. 1993;2:137-43.

2. Kapteijn BAE, Nieweg OE, Liem IL, Oooi WJ, Balm AJ, Muller SH, Peterse JL, Vadés Olmos RA, Hoefnagel CA, Kroon BB. Localizing the sentinel node in cutaneous melanoma: gamma probe detection versus blue dye. Ann Surg Oncol. 1997;4(2):156-60.

3. Krag DN, Meijer SJ, Weaver DL, Loggie BW, Harlow SP, Tanabe KK, Laughlin EH, Alex JC. Minimal-Access Surgery for Staging of Malignant Melanoma. Arch Surg. 1995;130(6):654-58.

4. Mariani G, Gipponi M, Moresco L, Villa G, Bartolomei M, Mazzarol G, Bagnara MC, Romanini A, Cafiero F, Paganelli G, Strauss HW. Radioguided sentinel lymph node biopsy in malignant cutaneous melanoma. J Nucl Med. 2002;43(6):811-27.

5. Kapteijn BAE, Nieweg OE, Petersen JL, Rutgers EJ, Hart AA, van Dongen JA. Identification and biopsy of the sentinel lymph node in breast cancer. Eur J Surg Oncol. 1998;24(5):427-30.

6. Krag DN, Weaver DL, Alex JC, Fairbanks JT. Surgical resection and radiolocalization of the sentinel lymph node in breast cancer using a gamma probe. Surg Oncol. 1993;2(6):335-40.

7. Mariani G, Moresco L, Viale G, Villa G, Bagnasco M, Canavese G, Buscombe J, Strauss HW, Paganelli G. Radioguided sentinel lymph node biopsy in breast cancer surgery. J Nucl Med. 2001;42(8):1198-1215.
8. Levenback C, Coleman RL, Burke TW, Bodurka-Bevers D, Wolf JK, Gershenson DM. Intraoperative lymphatic mapping and sentinel node identification with blue dye in patients with vulvar cancer. Gynecol Oncol. 2001;83(2):276-81.

9. Alex JC, Weaver DL, Fairbanks JT, Rankin BS, Krag DN. Gammaprobe guided lymph node localization in malignant melanoma. Surg Oncol. $1993 ; 2: 303-8$.

10. Bilchik AJ, Giuliano A, Essner R, Bostick P, Kelemen P, Foshag LJ, Sostrin S, Turner RR, Morton DL. Universal application of intraoperative lymphatic mapping and sentinel lymphadenectomy in solid neoplasms. Cancer J Sci Am. 1998;4(6):351-8.

11. Alex JC, Krag DN. The gamma-probe-guided resection of radiolabeled primary lymph nodes. Surg Oncol Clin N Am. 1996;5(1):33-41.

12. Murray DR, Carlson GW, Greenlee R, Alazraki N, Fry-Spray C, Hestley A, Poole R, Blais M, Timbert DS, Vansant J. Surgical management of malignant melanoma using dynamic lymphoscintigraphy and gamma probe-guided sentinel lymph node biopsy: the Emory experience. Am Surg. 2000;66(8):763-7.

13. Oliveira Filho RS, Tovo Filho R, Eto CM, Bortoletto MCC. Mapeamento linfático intra-operatório para melanoma estádio clínico I: uma técnica promissora. An Bras Dermatol. 1994;75(5):573-80.

14. Oliveira Filho RS, Oliveira Santos ID, Ferreira LM, Almeida FA, Enokihara MM, Barbieri A, Tovo Filho R. Is intra-operative gamma probe detection really necessary for inguinal sentinel lymph node biopsy? São Paulo Med J. 2000;118(6):165-8.

15. Pijpers R, Collet GJ, Meijer S, Hoekstra OS. The impact of dynamic lymphoscintigraphy and gamma probe guidance on sentinel node biopsy in melanoma. Eur J Nucl Med. 1995;22(11):1238-1.

16. Ross MI, Reintgen D, Balch CM. Selective lymphadenectomy: emerging role for lymphatic mapping and sentinel node biopsy in the management of early stage melanoma. Sem Surg Oncol. 1993;9:219-3.

17. Cabanas RM. An approach for the treatment of penile carcinoma. Cancer. 1977;39:456-6.

18. Morton DL, Wen DR, Wong JH, Economou JS, Cagle LA, Storm FK, Foshag LJ, Cochran AJ. Technical details of intraoperative lymphatic mapping for early stage melanoma. Arch Surg. 1992;127(4):392-9.

19. Morton DL, Thompson JF, Essner R, Elashoff R, Stern SL, Nieweg OE, Roses DF, Karakousis CP, Mozzillo N, Reintgen D, Wang HJ, Glass EC, Cochran AJ. Validation of the accuracy of intraoperative lymphatic mapping and sentinel lymphadenectomy for early-stage melanoma: a multicenter trial. Multicenter Selective Lymphadenectomy Trial Group. Ann Surg. 1999;230(4):453-63.

20. Greene F, Page DL, Fkeming ID, Frit AG, Balch CM, Haller DG, Morrow M. Carcinoma of the skin. AJCC Cancer Staging Handbook. New York: Springer Verlag; 2002.

21. Cox CE, Bass SS, McCann CR, Ku NN, Berman C, Durand K, Bolano M, Wang J, Peltz E, Cox S, Salud C. Lymphatic mapping and sentinel lymph node biopsy in patients with breast cancer. Ann Rev Med. 2000;51:525-42.

22. Sato K, Uematsu M, Saito T, Ishikawa H, Yamasaki T, Tamaki K, Tamai S, Kusano S, Hiraide H, Mochizuki H. Indications and technique of sentinel lymph node biopsy in breast cancer using 99m-technetium labeled tin colloids. Breast Cancer. 2000;7(1):95-8.

23. Sliutz G, Reinthaller A, Lantzsch T, Mende T, Sinzinger H, Kainz C, Koelbl H. Lymphatic mapping of sentinel nodes in early vulvar cancer. Gynecol Oncol. 2002;84(3):449-52.

24. Albertini JJ, Cruse CW, Rapaport D, Wells K, Ross M, DeConti R, Berman CG, Jared K, Messina J, Lyman G, Glass F, Fenske N, and D S Reintgen. Intraoperative radio-lympho-scintigraphy improves sentinel lymph node identification for patients with melanoma. Ann Surg. 1996;223(2):217-24.

25. Belli F, Lenisa L, Clemente C, Tragni G, Mascheroni I, Gallino G, Cacinelli N. Sentinel node biopsy and selective dissection for melanoma nodal metastases. Tumori. 1998;84:24-8. 
26. Bostick P, Essner R, Glass E, Kelley M, Sarantou T, Foshag LJ, Morton D. Comparison of blue dye and probe-assisted intraoperative lymphatic mapping in melanoma to identify sentinel nodes in 100 lymphatic basins. Arch Surg. 1999;134(1):43-9.

27. Cserni G, Rajtar M, Boross G, Sinkó M, Svébis M, Báltas B. Comparison of vital dye-guided lymphatic mapping and dye plus gamma probeguided sentinel node biopsy in breast cancer. World J Surg. 2002;26:592-7.

28. Oliveira Filho RS, Lima EN. Selective lymphadenectomy and sentinel node biopsy in cutaneous melanoma stage I and II. Acta Oncol Bras. 1997; 17:74-7.

29. Pijpers R, Meijer S, Hoekstra OS, Collet GJ, Comans EF, Boom RP, Diest PJ, Teule GJ. Impact of lymphoscintigraphy on sentinel node identification with technetium-99m-colloidal albumin in breast cancer. J Nucl Med. 1997;38(3):366-8.
30. Wong JK, Cagle LA and Morton DL. Lymphatic drainage of skin to a sentinel lymph node in a feline model. Ann Surg. 1991;214:637-41.

31. Costa FE, Rela PR, Oliveira IB, Perreira, MCC, Hamada, MM. Surgical gamma probe with $\mathrm{TIBr}$ semicondutor for identification of sentinel lymph node. IEEE Trans Nucl Sci. 2006;53(3):1403-7.

32. Silva IJO, Khoury HJ, Lemos MRL, Almeida Filho PJ, Guimarães MCC. Estudo do efeito do uso colimador na sonda gama utilizada em cirurgia radioguiada. Radiol Bras. 2006,39(6):429-4.

\section{Acknowledgements}

We are grateful to Diagnostics Unit of the Samaritan Hospital for having made available the use of the imported intraoperatory gamma detection equipment

\section{Correspondence:}

Paula Cristina Fada dos Santos

Division of Plastic Surgery, Department of Surgery

Federal University of Sao Paulo

Rua Napoleão de Barros, $715 / 4^{\circ}$ andar

04024-0022 Sao Paulo - SP Brazil

Phone: (55 11)5576-4065/5576-4118

ppfada@hotmail.com

Conflict of interest: none

Financial source: none

Received: December 14, 2008

Review: February 18, 2009

Accepted: March 24, 2009

\section{How to cite this article}

Santos PCF, Santos IDAO, Nahas FX, Oliveira Filho RS, Ferreira LM. National equipment of intraoperatory gamma detection in the identification of sentinel lymph node in animal model. Acta Cir Bras. [serial on the Internet] 2009 May-Jun;24(3). Available from URL: http://www.scielo.br/acb 